\title{
Current Overview on the Effects of COVID-19 Disease on Maternal and Neonatal Health; Narrative Review
}

\author{
(1) Illke Özer Aslan, ${ }^{1}$ [1] Mustafa Törehan Aslan, ${ }^{2}$ (1) Öner Özdemir ${ }^{3}$
}

\author{
'Department of Obstetrics and \\ Gynecology, University of Health \\ Sciences, Bakırköy Dr. Sadi Konuk \\ Training and Research Hospital, \\ Istanbul, Turkey \\ 2Department of Pediatrics, \\ Istanbul University Istanbul Faculty \\ of Medicine, Division of \\ Neonatology, Istanbul, Turkey \\ ${ }^{3}$ Department of Pediatrics, \\ Sakarya University, Training and \\ Research Hospital, Division of \\ Allergy and Immunology, \\ Sakarya, Turkey \\ Submitted: 01.05.2020 \\ Accepted: 12.07 .2020 \\ Correspondence: Illke Özer Aslan, \\ Sağlık Bilimleri Üniversitesi, \\ Bakırköy Dr. Sadi Konuk Eğitim ve \\ Araștırma Hastanesi, \\ Kadın Hastalıkları ve Doğum \\ Anabilim Dal, Istanbul, Turkey \\ E-mail: ilkeozeraslan@gmail.com

\begin{tabular}{r}
\hline Keywords: Birth; \\
COVID- I 9; newborn; \\
pregnancy. \\
Cc) (i) (5) \\
BY \\
Atribution-Noncommercial 4.0 International License.
\end{tabular}

\section{INTRODUCTION}

The novel coronavirus (SARS-CoV-2: Severe Acute Respiratory Syndrome Coronavirus-2) infection, which appeared in Wuhan, China in December 2019, spread rapidly within a short period of time and was accepted as a pandemic by WHO (World Health Organization) as of March II, 2020 has become an important life- threatening factor. ${ }^{[1,2]}$ This new virus was firstly named $2019-\mathrm{nCoV}$ (novel CoV), but was later named SARS-CoV-2. In early January 2020, it was isolated in laboratories in China. ${ }^{[3]}$ Later, it became an increasingly widespread respiratory tract infection that can cause serious pneumonia and death worldwide. Although there is a rapid increase in the available information regarding the genetic, virological, epidemiological and clinical aspects of this disease, 7 coronaviruses are known that can cause infection in humans to date. This novel coronavirus, recently causing COVID-19 disease, has been shown to cause fatal lung pathologies. ${ }^{[4]}$ The virus can be transmitted from infected individuals through cough, sneezing droplets as well as contact with the patient's hand spoiled with the contaminated surfaces by touching the eye, mouth and nasal mucosa. ${ }^{[5]} \mathrm{It}$ is estimated that the respiratory droplet does not go beyond about 2 meters. 
Contagion has also been reported from asymptomatic individuals. ${ }^{[6]}$ Incubation time is considered to be an average of 5 days (2-14 days). However, among the some recent cases, it has been reported that there are no signs of contact with infected people. ${ }^{[7]}$ The average age is 49-56 years and additional predisposing disease was detected in $1 / 3$ to half of the cases. ${ }^{[8]}$ Among the most common symptoms of infection are respiratory symptoms, fever, cough, and dyspnea. In more serious cases, pneumonia, severe acute respiratory infection, kidney failure or even death due to multiple organ failure may occur. The death rate in cases occurring in China is around $2 \%$. However, this rate may vary depending on the changes in the genetic structure of the virus or the treatment. No vaccine or antiviral treatment for the virus has yet been found. [6] An important question we have in mind is the possibility of higher susceptibility risk to SARS-CoV-2, related to physiological changes in pregnant women. However, when we look at the literature, there is no evidence that pregnant women are more susceptible to SARS-CoV-2 infection. ${ }^{[9]}$ Another question that remains unanswered is whether SARS-CoV-2 is transmitted vertically from pregnant women to the fetus. If it is being transferred, how its mechanism is occurred. This is not only an important public health problem, but it is also an obstetric management problem for both pregnant and infant. Considering the previous experience, this becomes even more important when we consider that other agents such as Zika virus, Ebola virus are transmitted vertically and threaten the life of the infected mother and fetus. ${ }^{[10,11]}$

\section{Current clinical features, obstetric and neonatal reflections of pregnant women with covid-19 disease}

In the current literature, when the clinical symptoms of the patients in a series of 9 pregnancies with COVID-19 disease positive were examined, it was observed that they were similar to those who were not pregnant. Although 7 patients had fever, 4 had coughs, 3 had muscle pain, 2 had sore throat, 5 had lymphopenia, and 3 had aminotransferase elevation. Mechanical ventilation was not required despite pneumonia development in all cases. ${ }^{[12]}$ In another study that examined the clinical symptoms and thorax computed tomography findings of 15 pregnant women with confirmed COVID-19 disease, 19 pregnant with suspected COVID-19 disease, cough was observed in 13 cases and lymphopenia was the most common laboratory finding in 12 cases. In 10 cases, pregnancy was completed by cesarean and in I case, it was completed by normal vaginal delivery. The pregnancy of the other 4 cases has been continuing. Neonatal asphyxia, neonatal death, preterm birth or miscarriage has not been reported in any baby born from these pregnant women. It was found that pregnancy and birth did not aggravate the clinical course. ${ }^{[13]}$

108 pregnant women were investigated in a review of all case reports and case series between 12 February 2020 and 4 April 2020. It has been reported that most cases are in the last trimester and are admitted to the hospital with $68 \%$ fever and $34 \%$ cough symptoms. While C-reactive protein (CRP) levels were found to be increased in $70 \%$ of cases, lymphopenia was found in $59 \%$ of cases. The delivery of $91 \%$ of the cases was performed by cesarean section and 3 pregnant women were followed up in the postpartum intensive care unit. But no maternal death has been reported. Only one neonatal death and one intrauterine fetal death were detected. ${ }^{[14]}$

In another study comprising of 37 pregnant women and 38 newborns, 29 pregnant women were delivered by cesarean while 8 pregnant women gave normal birth. While preterm delivery was reported in 7 pregnancies between 30-33 weeks of gestation, all other pregnant had term delivery. Although no mother needed mechanical ventilation, the patients were given non-invasive oxygen support via nasal cannula only with the combination of antiviral, and antibiotic therapies. Only one patient needed to follow-up in the intensive care unit, and her baby was closely monitored in neonatal intensive care. The most common symptoms in these cases were fever, cough and chest pain, as in other studies mentioned. ${ }^{[15]}$

Similarly, the most frequently found laboratory finding in other publications is lymphopenia. All pregnant women in the study gave birth to healthy newborns with Apgar score between 8 and 10. Asphyxia, cyanosis or any congenital anomalies have not been reported in neonates. Sample locations taken from the newborn after delivery were examined by RT-PCR from the oropharynx, umbilical cord blood, amniotic fluid and blood samples. Also, RT-PCR was examined from the breast milk sample. Considering neonatal results, there is no evidence of teratogenicity, fetal transmission through the placenta and/or breast milk after birth. When neonates with positive COVID-19 disease are examined, the transmission is thought to be via respiratory droplet due to factors such as cough from the mother or other immediate perinatal environment. Development of symptoms in neonates occurs between 5 and 17 days after birth. The most common symptoms during follow-up were vomiting, fever, cough, pneumothorax, impaired liver function tests, thrombocytopenia and pulmonary changes in thorax computed tomography (CT). All newborns born from the mother confirmed of COVID-19 disease in the study were fed with formula. ${ }^{[15]}$

In another study in which 16 cases with pneumonia due to COVID-19 disease and 18 suspicious cases who applied for delivery in the 3rd trimester were examined, the pregnancy of 2 cases was terminated with a normal vaginal delivery while the pregnancy of other cases was terminated with a cesarean delivery. While symptoms such as fever and cough were observed in a few cases, the findings of the neonates observed were typical in thorax computed tomography. Compared to the control group, the WBC count and neutrophil counts were 
low in COVID-19 patients, whereas WBC, neutrophil, eosinophil and CRP levels increased in the postpartum period. Six of the cases had preterm delivery, and none of them had respiratory failure during their hospital stay. When neonates were examined, no serious neonatal complications were observed, and no signs of disease were encountered in any of them. ${ }^{[16]}$

In a different study examining 32 pregnant women infected with SARS-CoV-2, 7 pregnant women (22\%) were asymptomatic, while 2 patients needed admission in the intensive care unit, but no maternal death was observed. Although there were limited cases when compared to infections such as SARS and MERS in the past, COVID-I 9 disease has been observed to be less fatal in pregnant women. Twenty-seven cases were delivered by cesarean section, and preterm delivery was observed in I5 cases (47\%). It is unclear whether preterm deliveries are spontaneous or iatrogenic. latrogenic deliveries were mostly due to indications caused by maternal viral infection. When neonatal results were analyzed, it was observed that only one case had neonatal death. No vertical transmission was observed in neonates. Delivery patterns were determined by obstetric indications and it was not thought to be associated with pregnancy loss or intrauterine growth retardation as seen in SARS and MERS infections. ${ }^{[17]}$

In a single-center retrospective study examining 7 cases with confirmed COVID-19 disease, pregnancy of all cases was terminated by cesarean section. Compared to the non-pregnant population, the prognosis of the patients did not show any risk increase, and none of the patients required intensive care. In all cases, birth weight and Apgar scores of newborns were within normal limits. Since 4 of the neonates did not have any symptoms, they were discharged without SARS-CoV-2 testing and it was observed that there was no problem in their follow-up. In the other 3 neonates, the SARS-CoV-2 test was performed, only one of them was positive. In the follow-up of this positive case, no fever or cough was detected, but only mild respiratory symptoms. There were no problems in the follow-up of the patient, whose symptoms were regressed and discharged after two weeks. ${ }^{[18]}$

In a further study evaluating 9 pregnant cases and 10 neonates (one of them was twin pregnancy), 4 cases were term and 6 cases were preterm. Clinical symptoms of fever, vomiting, thrombocytopenia, impaired liver function tests, tachycardia, and pneumothorax have also been observed in neonates whose main symptom was respiratory distress. Until the publication date of the article, 5 patients were discharged by completing their treatment. While four neonates were kept under observation in the hospital for follow-up, I case died. The results were negative in PCR samples taken on postnatal $9^{\text {th }}$ day. When the neonatal results of pregnant women with COVID- 19 disease were examined, there was no definite evidence in relation to this condition, although preterm labor, fe- tal distress and respiratory distress syndrome can cause negative results. Vertical transmission has not been proven. ${ }^{[19]}$

As a summary; COVID-19 disease has spread rapidly around the world and has turned into a pandemic. When we look at the limited data in the literature, an increased sensitivity to COVID-1 9 disease in pregnant women compared to the general population has not been reported. However, it is accepted that the immune systems of pregnant women are suppressed. Therefore, pregnant women are generally more sensitive to diseases than non-pregnant women. Higher morbidity and mortality require the management of suspicious or infected pregnant women by multidisciplinary teams with sufficient knowledge and equipment in this regard, due to the high mortality rates caused by genomically similar viruses, SARS-CoV and MERS-CoV infections in pregnant women. Although there is a limited amount of information in pregnant women, there are no significant differences in terms of symptoms, radiological and laboratory findings compared to those who are not pregnant in general. In a limited number of studies on this subject, the mortality rate is around $1-4 \%$.

There is no evidence yet that the infection has passed from the mother to the baby. Aggressive infection control management, early mechanical ventilation in progressive respiratory symptoms, oxygen therapy, avoiding excess fluid treatment, and close fetal and uterine monitoring come to the forefront in pregnancy and birth management. Since the infection is very new, there are no large case series and randomized controlled studies in neonates. Although the case definitions of neonates are similar to those in adults, neonates may be considered to be at greater risk since their immune systems are not sufficiently developed. More care should be taken in newborns who have a history of contact in severe cases or who have risk factors such as congenital heart disease and respiratory anomaly. Considering that it has similar genomic structures and clinical features, studies conducted in patients with SARS infection also have perinatal infection in pregnant women, and no evidence of its occurrence in newborns was found. [20] In Table I, a summary of the studies examining the relationship between COVID-19 disease, pregnancy and neonatal period is mentioned.

\section{CONCLUSION}

In the light of the available data, it is thought that pregnancy is not a risk factor in the course of COVID-19 disease, but it is often seen in the cases in the third trimester. It is striking that the maternal and neonatal effects of these infected cases, infected during the late pregnancy period are quite good. In the cases of first and second trimesters, more studies are needed in order to determine long-term results and to clarify the vertical transmission risk. 
Table I. Current literature on COVID-19 disease, pregnancy and/or neonatal period

\begin{tabular}{|c|c|c|c|c|}
\hline Author & Year & Country & Title & Key findings \\
\hline Liu et al. ${ }^{[13]}$ & 2020 & China & $\begin{array}{c}\text { Coronavirus Disease } 2019 \\
\text { (COVID-19) During Pregnancy: } \\
\text { A Case Series }\end{array}$ & $\begin{array}{l}\text { No evidence to suggest } \\
\text { the potential risk of } \\
\text { intrauterine vertical } \\
\text { transmission }\end{array}$ \\
\hline Zaigham et al. ${ }^{[14]}$ & 2020 & Sweden & $\begin{array}{l}\text { Maternal and } \\
\text { perinatal outcomes with } \\
\text { COVID-19: A systematic } \\
\text { review of } 108 \text { pregnancies }\end{array}$ & $\begin{array}{l}\text { Vertical transmission of the } \\
\text { COVID-19 could not } \\
\text { be ruled out. Careful } \\
\text { monitoring of pregnancies } \\
\text { with COVID-19 and } \\
\text { measures to prevent } \\
\text { neonatal infection are } \\
\text { warranted. }\end{array}$ \\
\hline Panahi et al. ${ }^{[15]}$ & 2020 & Iran & $\begin{array}{c}\text { Risks of Novel } \\
\text { Coronavirus Disease } \\
\text { (COVID-19) in } \\
\text { Pregnancy; a } \\
\text { Narrative Review }\end{array}$ & $\begin{array}{l}\text { COVID-19 can cause fetal } \\
\text { distress, miscarriage, } \\
\text { respiratory distress and } \\
\text { preterm delivery in } \\
\text { pregnant women but does } \\
\text { not infect newborns. There } \\
\text { has been no report of } \\
\text { vertical transmission } \\
\text { in pregnancy, and it has } \\
\text { been found that clinical } \\
\text { symptoms of COVID-19 in } \\
\text { pregnant women are not } \\
\text { different from those of } \\
\text { non-pregnant women }\end{array}$ \\
\hline Li et al. ${ }^{[16]}$ & 2020 & China & $\begin{array}{l}\text { Maternal and } \\
\text { neonatal outcomes of } \\
\text { pregnant women with } \\
\text { COVID-19 pneumonia: } \\
\text { a case-control study }\end{array}$ & $\begin{array}{l}\text { Severe maternal and } \\
\text { neonatal complications } \\
\text { were not observed in } \\
\text { pregnant women with } \\
\text { COVID-19 pneumonia } \\
\text { who had vaginal delivery } \\
\text { or caesarean section. Mild } \\
\text { respiratory symptoms } \\
\text { of pregnant women with } \\
\text { COVID- } 19 \text { pneumonia } \\
\text { highlight the need of } \\
\text { effective screening on } \\
\text { admission }\end{array}$ \\
\hline Mullins et al. ${ }^{[17]}$ & 2020 & UK & $\begin{array}{l}\text { Coronavirus in pregnancy } \\
\text { and delivery: rapid review }\end{array}$ & $\begin{array}{l}\text { Compared with SARS and } \\
\text { MERS, COVID-19 } \\
\text { appears less lethal and } \\
\text { delivery mode be } \\
\text { determined primarily by } \\
\text { obstetric indication and } \\
\text { recommends against } \\
\text { routine separation of } \\
\text { affected mothers and their } \\
\text { babies. }\end{array}$ \\
\hline Yu et al. ${ }^{[18]}$ & 2020 & China & $\begin{array}{l}\text { Clinical features and } \\
\text { obstetric and neonatal }\end{array}$ & $\begin{array}{l}\text { The maternal, fetal, and } \\
\text { neonatal outcomes of }\end{array}$ \\
\hline
\end{tabular}


Table I. (Current literature on COVID-19 disease, pregnancy and/or neonatal period)

\begin{tabular}{|c|c|c|c|c|}
\hline Author & Year & Country & Title & Key findings \\
\hline Zhu et al. ${ }^{[19]}$ & 2020 & China & $\begin{array}{l}\text { outcomes of pregnant } \\
\text { patients with COVID-19 } \\
\text { in Wuhan, China : a } \\
\text { retrospective, } \\
\text { single-center, descriptive study }\end{array}$ & $\begin{array}{l}\text { patients who were infected } \\
\text { in late pregnancy appeared } \\
\text { very good. The clinical } \\
\text { characteristics of these } \\
\text { patients with COVID-I9 } \\
\text { during pregnancy were } \\
\text { similar to those of } \\
\text { non-pregnant adults with } \\
\text { COVID-19 that have been } \\
\text { reported in the literature. } \\
\text { Perinatal } 2019 \text {-nCoV } \\
\text { infection may have adverse } \\
\text { effects on newborns, } \\
\text { causing problems such } \\
\text { as fetal distress, premature } \\
\text { labor, respiratory distress, } \\
\text { thrombocytopenia } \\
\text { accompanied by abnormal } \\
\text { liver function, and even } \\
\text { death. However, vertical } \\
\text { transmission of } 2019 \text {-nCoV } \\
\text { is yet to be confirme }\end{array}$ \\
\hline
\end{tabular}

\section{Peer-review}

Internally peer-reviewed.

\section{Conflict of Interest}

None declared.

\section{REFERENCES}

1. Zhu N, Zhang D, Wang W, Li X, Yang B, Song J, et al; China Novel Coronavirus Investigating and Research Team. A Novel Coronavirus from Patients with Pneumonia in China, 2019. N Engl J Med 2020;382:727-33. [CrossRef]

2. Huang C, Wang Y, Li X, Ren L, Zhao J, Hu Y, et al. Clinical features of patients infected with 2019 novel coronavirus in Wuhan, China. Lancet 2020;395:497-506. [CrossRef]

3. World Health Organization. Naming the coronavirus disease (COVID-2019) and the virus that causes it. Available at: https:// www.who.int/emergencies/diseases/novel-coronavirus-2019/technicalguidance/naming-the-coronavirus-disease-(covid-2019)-andthe-virus-that-causes-it. Accessed Feb 23, 2020.

4. Xu Z, Shi L, Wang Y, Zhang J, Huang L, Zhang C, et al. Pathological findings of COVID-19 associated with acute respiratory distress syndrome. Lancet Respir Med 2020;8:420-2. [CrossRef]

5. T.C. Sağlık Bakanlığı, Halk Sağlı̆̆ı Genel Müdürlüğü. COVID-19 Rehberi. Available at: https://hsgm.saglik.gov.tr/tr/bulasici-hastaliklar/2019-n-cov.html. Accessed Sep 01, 2020.

6. McIntosh K. Coronavirus disease 2019 (COVID-19): Epidemiology, virology, and prevention. Available at: https://www.uptodate. com/contents/coronavirus-disease -2019-covid-19-epidemiologyvirology-and-prevention. Accessed Sep 01, 2020.

7. Rasmussen SA, Smulian JC, Lednicky JA, Wen TS, Jamieson DJ. Coronavirus Disease 2019 (COVID-19) and pregnancy: what obste- tricians need to know. Am J Obstet Gynecol 2020;222:415-26.

8. ACOG. Practice Advisory: Novel Coronavirus 2019 (COVID-19). Available at: https://www.acog.org/Clinical-Guidance-and-Publications/Practice- Advisories/Practice-Advisory-Novel-Coronavirus2019?:IsMobileSet=false. Accessed Mar 12, 2020.

9. RCOG. Coronavirus (COVID-19) _infection in pregnancy, 09/03/2020. Available at: https://www.rcog.org.uk/globalassets/ documents/gu_del_nes/coronaviruscovid-19- virusinfectioninpregnancy-2020-03-09.pdf. Accesed Mar 12, 2020.

10. Alvarado MG, Schwartz DA. Zika Virus Infection in Pregnancy, Microcephaly, and Maternal and Fetal Health: What We Think, What We Know, and What We Think We Know. Arch Pathol Lab Med 2017;141:26-32. [CrossRef]

11. Schwartz DA. Being Pregnant during the Kivu Ebola Virus Outbreak in DR Congo: The rVSV-ZEBOV Vaccine and Its Accessibility by Mothers and Infants during Humanitarian Crises and in Conflict Areas. Vaccines (Basel) 2020;8:38. [CrossRef]

12. Chen H, Guo J, Wang C, Luo F, Yu X, Zhang W, et al. Clinical characteristics and intrauterine vertical transmission potential of COVID-19 infection in nine pregnant women: a retrospective review of medical records. Lancet 2020;395:809-15. [CrossRef]

13. Liu D, Li L, Wu X, Zheng D, Wang J, Yang L, et al. Pregnancy and Perinatal Outcomes of Women With Coronavirus Disease (COVID-19) Pneumonia: A Preliminary Analysis. AJR Am J Roentgenol 2020;215:127-32. [CrossRef]

14. Zaigham M, Andersson O. Maternal and perinatal outcomes with COVID-19: A systematic review of 108 pregnancies. Acta Obstet Gynecol Scand 2020;99:823-9. [CrossRef]

15. Panahi L, Amiri M, Pouy S. Risks of Novel Coronavirus Disease (COVID-19) in Pregnancy; a Narrative Review. Arch Acad Emerg Med 2020;8:e34.

16. Li N, Han L, Peng M, Lv Y, Ouyang Y, Liu K, et al. Maternal and 
neonatal outcomes of pregnant women with COVID-19 pneumonia: a case-control study. Clin Infect Dis. 2020 Mar 30 [Epub ahead of print], doi: 10.1093/cid/ciaa352. [CrossRef]

17. Mullins E, Evans D, Viner RM, O'Brien P, Morris E. Coronavirus in pregnancy and delivery: rapid review. Ultrasound Obstet Gynecol 2020;55:586-92. [CrossRef]

18. Yu N, Li W, Kang Q, Xiong Z, Wang S, Lin X, et al. Clinical features and obstetric and neonatal outcomes of pregnant patients with
COVID-19 in Wuhan, China: a retrospective, single-centre, descriptive study. Lancet Infect Dis 2020;20:559-64. [CrossRef]

19. Zhu H, Wang L, Fang C, Peng S, Zhang L, Chang G, et al. Clinical analysis of 10 neonates born to mothers with 2019-nCoV pneumonia. Transl Pediatr 2020;9:51-60. [CrossRef]

20. Wong SF, Chow KM, Leung TN, Ng WF, Ng TK, Shek CC, et al. Pregnancy and perinatal outcomes of women with severe acute respiratory syndrome. Am J Obstet Gynecol 2004;191:292-7. [CrossRef]

\section{COVID-19 Hastalığının Anne ve Yenidoğan Sağlığı Üzerine Etkilerine Güncel Bakış;}

\section{Derleme}

2019'un sonlarında Çin'in Wuhan bölgesinde ortaya çıkan yeni koronavirüs enfeksiyonu (SARS-CoV-2 enfeksiyonu) kısa sürede hızla yayıldı. Birkaç ay sonra, DSÖ (Dünya Sağlık Örgütü) tarafından salgın olarak kabul edildi ve halk sağlığı için önemli bir tehdit haline geldi. Çin'de meydana gelen vakalarda ölüm oranı \%2 civarındaydı. COVID-19 hastalığı sırasında gebeliğin bir risk faktörü olmadığı düşünülse de, genellikle COVID-19'a rastalanan vakalar üçüncü trimesterde idi. Bu enfekte vakaların geç gebelik dönemindeki anne ve yenidoğan etkilerinin oldukça iyi olması dikkat çekicidir. Uzun dönem sonuçlarını belirlemek ve vertikal geçiş riskini açıklığa kavuşturmak için birinci ve ikinci trimesterde daha fazla vakayı inceleyen daha ileri çalışmalara ihtiyaç vardır.

Anahtar Sözcükler: COVID-19; doğum; gebelik; yenidoğan. 